REVISTA DE DERECHO UNED, NÚM. 12, 2013

\title{
LA VALORACIÓN DE LA VIVIENDA PROTEGIDA MADRILEÑA EN LA LIQUIDACIÓN DE LA SOCIEDAD DE GANANCIALES
}

\section{LIQUIDATION OF THE CONJUGAL PARTNERSHIP PROTECTED HOUSING: THE CASE OF THE COMUNIDAD DE MADRID}

\author{
DANIEl MonTERo FERREIRA \\ Doctorando en Derecho Civil (UNED)* \\ Abogado
}

Resumen: Este trabajo aporta una alternativa que sobre la valoración de la vivienda protegida madrileña con motivo de la liquidación de la sociedad de gananciales, da la jurisprudencia del Tribunal Supremo español

Palabras clave: Liquidación de la sociedad de gananciales, vivienda protegida, valoración.

Abstract: This article provides an alternative that the valuation of subsidized housing in Madrid on the occasion of the liquidation of the conjugal partnership, given the Spanish Supreme Court's jurisprudence.

Key words: Liquidation of the conjugal partnership protected housing, valuation.

Recepción original: 17/06/2013

Aceptación original: 18/06/2013

Agradezco al Departamento de Derecho civil todas las facilidades y apoyo que me han prestado y, en especial, a su Director el Catedrático de Derecho civil de la UNED, Prof. Carlos LASARTE ÁLVAREZ, así como a sus discípulas las Profesoras M. ${ }^{a}$ Fernanda Moretón Sanz y Araceli Donado Vara, Directoras de mi tesis doctoral, por el apoyo, revisiones y observaciones hechas en esta investigación. 
Sumario: I. Planteamiento general. II. Viviendas de protección oficial: 1. Definición y requisitos para obtener esta calificación, especialmente en la Comunidad de Madrid. 2. Sistema de descalificación, especialmente en la Comunidad de Madrid. III. Valoración de la vivienda de protección oficial en la liquidación de una sociedad de gananciales: evolución jurisprudencial. IV. Opción personal: imposibilidad de utilizar como criterio el acogido para la validez de los contratos de compraventa con sobreprecio (criterios jurisprudenciales en esta materia), criterio que se propone y justificación del mismo. V. Bibliografía y fuentes consultadas. VI. Índice de resoluciones judiciales utilizada

\section{PLANTEAMIENTO GENERAL}

Es bien sabido que, ante una crisis matrimonial de una pareja acogida al régimen económico de la sociedad de gananciales y como efecto común en los casos de nulidad, separación o divorcio planteados en sede judicial ${ }^{1}$, dicha sociedad habrá de ser disuelta y posteriormente liquidada ${ }^{2}$. Esto es, serán repartidos, entre los ex-cónyuges, por mitad los bienes gananciales, atribuyendo su titularidad a uno u otro. De modo que para liquidar la sociedad de gananciales,

\footnotetext{
1 Vid., artículo 90 E) del Código civil.

2 Vid., artículos 1.392 y sigs. del Código civil, en materia de disolución y liquidación de la sociedad de gananciales, sobre los que PAZ-ARES RODRÍGUEZ aclara: «Se recogen en este precepto las denominadas causas de disolución automática de la sociedad de gananciales. Este automatismo viene dado por la no necesidad de pronunciamiento judicial ad hoc y por la no exigencia de más requisito que la concurrencia de la causa. Como veremos, fallece un cónyuge o se decreta el divorcio e ipso iure deja de existir el consorcio conyugal, es decir, dejan de ser gananciales los frutos y rendimientos de los cónyuges (si sobreviven), y se pone en marcha todo el mecanismo liquidatorio" (Comentario del Código Civil, Tomo II, Ministerio de Justicia, Madrid, 1993, 2. ${ }^{a}$ ed., pág. 759). Como es sabido, la liquidación de la sociedad legal de gananciales se rige por los artículos 1.396 y siguientes del Código, exigiendo un conocimiento exacto de todas las partidas del activo y pasivo en comunidad, conforme preceptúa el citado artículo, inventario que ha de incluir lo que se debe en cada una de las partidas (arts. 1.397 y $1.398 \mathrm{Cc}$ ), cuyas operaciones requieren ciertas formalidades (arts. 1.013 a 1.034 Cc). Según lo determinado en el artículo 1.396 bajo el nombre de liquidación de la sociedad legal de gananciales, se comprenden todas las operaciones necesarias para determinar si existen gananciales y su distribución por mitad entre ambos cónyuges. De conformidad al artículo 1.398, el inventario deberá reflejar la verdadera situación de un patrimonio. No se habrá formulado debidamente si no se incluye en él, tanto el pasivo como el activo. Por su parte, el artículo 1.066 del Real Decreto de 3 de febrero de 1881, de promulgación de la antigua LEC perseguía la exacta descripción de los bienes a liquidar y fiel reflejo de la realidad. El artículo 1.404, establece un criterio de equidad entre los cónyuges y exige un reparto por mitad de los bienes obtenidos constante matrimonio.
} 
resulta preciso formar un inventario de los bienes y derechos que la integren, así como la correspondiente valoración o avalúo ${ }^{3}$.

Al llegar al punto de la valoración de una vivienda protegida, procederá también el avalúo de este bien. Pues bien, para ilustrar el objeto de estas líneas, vamos a plantear un supuesto de hecho en el que, entre los bienes de la concreta sociedad de gananciales reflejados en su correspondiente inventario, figure una vivienda de protección pública. Dada esta circunstancia, habrá de despejarse las controversias o interrogantes que puedan existir en torno a ella, por lo que en definitiva, habrá de imputarse y determinarse el valor de la vivienda de protección oficial.

En este sentido, para la determinación del valor de ese inmueble ganancial calificado de vivienda protegida, cabe establecer diferentes cuantías. Así, es posible imputar el valor máximo fijado administrativamente según el módulo aplicable, o por el contrario, el valor de mercado en el momento del avalúo. Seleccionamos, de entre las eventuales fórmulas, estas dos (valor máximo administrativo vs. valor de mercado) pese a que no agotemos la cuestión, ya que podrían ser aceptables otros patrones valorativos.

La respuesta es el nudo gordiano que posibilitará una liquidación de sociedad de gananciales equilibrada ${ }^{4}$, con asignación de lotes equitativos para ambos ex-cónyuges ${ }^{5}$.

Adicionalmente y con carácter previo, conviene tener presente que este estudio se dirige a la adjudicación de la titularidad de la propiedad, de modo que excluimos las controversias que puedan girar en torno a la atribución del uso de dicha vivienda a uno u otro de los ex-cónyuges. En este último sentido, si el matrimonio ha tenido

3 Por su parte, SÁNCHEZ CALERO, donde como suele ser habitual en la totalidad de los estudios al respecto, recuerda la asistemática ordenación del régimen económico matrimonial aclarando que «Constituye el Derecho de obligaciones una de las cuatro partes especiales en que tradicionalmente se distribuye el Derecho civil para su estudio y exposición. A esta materia dedica nuestro Código Civil su libro IV, bajo la rúbrica De las obligaciones y contratos, si bien con su habitual desorden sistemático regula dentro de este libro algunas materias que no responden a su enunciado (p. ej., todo el régimen económico del matrimonio, (...)» [Curso de Derecho Civil, Coord., Tirant lo Blanch, Valencia, 2012, 6. ${ }^{\mathrm{a}}$ ed., pág. 26].

4 Cfr. VILLAGRASA ALCAIDE, Carlos (Coord.), Derecho de Familia, Bosch, Barcelona 2011, 1. ${ }^{\text {a }}$ ed., págs. 201 a 204.

5 MORALES MORENO afirma sobre la ejecución no dineraria que se trata de «una de las materias que ofrece más dificultad en la ejecución de las sentencias dictadas en procesos civiles y en especial en materia de familia» (Ejecución de las sentencias dictadas en los procedimientos de familia, Tirant lo Blanch, Valencia 2013, 1. ${ }^{\mathrm{e}}$ ed., pág. 18). 
hijos y en el momento del divorcio aún menores de edad, salvo que los padres se pongan de acuerdo sobre el uso de la vivienda familiar en el convenio regulador, el juzgado ope legis, se pronunciará sobre la atribución del uso de la vivienda familiar. En principio, atribuirá el uso quien permanezca con los hijos, o en su defecto, al más necesitado de protección. Por supuesto, con independencia de quien sea o resulte propietario de la vivienda protegida ${ }^{6}$.

En la actualidad, el estado del mercado inmobiliario hace que las valoraciones y, en definitiva, el precio de las viviendas sin protección pública, no difiere tanto, como ocurría años atrás, de las viviendas protegidas. Por tanto, en estos momentos y frente a la situación económica inmediatamente anterior, la repercusión del avalúo de la vivienda protegida con un criterio u otro en la liquidación de la sociedad de gananciales se ha ido aproximando, aun cuando no sea equivalente.

\section{CUESTIONES SOBRE LAS VIVIENDAS DE PROTECCIÓN OFICIAL}

\section{Definición y requisitos para obtener esta calificación, especialmente en la Comunidad de Madrid}

Téngase en cuenta que la protección oficial, estatal -según haya sido denominada-, a la vivienda, o más acertadamente, la promoción y acceso a la vivienda, tiene su antecedente legislativo más inmediato en la Ley de 11 de junio de 1911, sobre Habitaciones Baratas, hasta la actualidad de forma ininterrumpida ${ }^{7}$.

La forma de establecer este tipo de incentivos, ayudas o facilidades de acceso mediante compra, cesión o arrendamiento a sus inquilinos, la ha realizado el Estado ${ }^{8}$ mediante mecanismos más o

6 Sobre la atribución del uso de la vivienda familiar a los hijos mayores de edad, CASTRO MARTÍN evidencia los efectos de la STS de 4 de julio de 2011 ya que «en los supuestos en los que los hijos hayan alcanzado la mayoría de edad el criterio prioritario para la atribución del uso de la vivienda familiar, será el determinado por el párrafo $3 .^{\circ}$, y no el párrafo $1 .^{\circ}$ del artículo 96 CC, según el cual: no habiendo hijos, podrá acordarse de que el uso de tales bienes, por el tiempo que prudencialmente se fije, corresponda al cónyuge no titular siempre que, atendidas las circunstancias, lo hicieran aconsejable y su interés fuera el más necesitado de protección» (El Derecho de

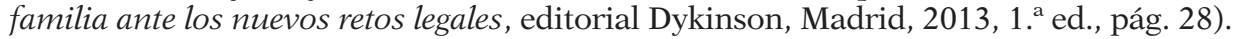

7 Eso sí, con distinta intensidad y acierto.

8 Dice al respecto, BLANCO BAREA «La existencia de un Estado de Derecho capaz de aprobar normas de funcionamiento y normas de regulación de cualquier 
menos similares, sin embargo, los fundamentos en que se apoya esta normativa, desde un punto de vista histórico-jurídico, son sensiblemente distintos. Dichas normas ${ }^{9}$ estaban encaminadas a atender necesidades de carácter social, pese a que en aquellos momentos aún no se habían reconocido derechos de carácter social. De modo que obedecía a la tutela singular de los ciudadanos más que al reconocimiento de derechos subjetivos.

Nuestra Carta Magna en su artículo 47.1 sobre el «derecho a la vivienda» digna y adecuada, establece el deber programático de los poderes públicos para hacer efectivo tal derecho, dirigiendo el uso del suelo al interés general. Así declara: «Todos los españoles tienen derecho a disfrutar de una vivienda digna y adecuada. Los poderes públicos promoverán las condiciones necesarias y establecerán las normas pertinentes para hacer efectivo este derecho, regulando la utilización del suelo de acuerdo con el interés general para impedir la especulación» ${ }^{10}$.

Baste recordar que los principios rectores de la política social y económica informan la legislación positiva, la práctica judicial y la actuación de los poderes públicos, no pudiéndose exigir su cumplimiento. En este último sentido, las Administraciones deben procurar, en la medida de lo posible, promover las condiciones necesarias para hacer efectivo ese derecho ${ }^{11}$.

actividad, permite la utilización de su imperium para proteger a sus ciudadanos y regular comportamientos; es el primer estrato existente desde el punto de vista histórico para la concepción actual de Estado que ha ido evolucionando durante las dos últimas centurias hasta conjugar lo que hoy conocemos en la mayoría del mundo occidental como Estado Social y Democrático de Derecho. Estos distintos tipos de «Estado», pueden regular y de hecho así lo han hecho, el derecho al acceso a una vivienda mediante la articulación de mecanismos gubernamentales en función de la naturaleza jurídica y social de cada forma de Estado. Así, el Estado de Derecho permite la posibilidad de emanar normas que ordenen cualquier disciplina, como por ejemplo la materia que nos ocupa, las Viviendas Protegidas, tal y como se ha hecho en España durante prácticamente todo el siglo XX hasta la actual Constitución» (Viviendas de Protección Oficial (VPO): tramitación administrativa y ayudas: normativa estatal y autonómica, Comares, Granada, 2004, pág. 8).

9 En general toda la legislación de la llamada «Vivienda de Protección Oficial», hasta el año 1978.

10 Cfr. Comentarios a la Constitución Española de 1978, dirigidos por ALZAGA VILLAAMIL, Tomo IV, Edersa, Madrid 2006, págs. 305 a 340. En particular, «el moderno constitucionalismo atiende fundamentalmente a la dimensión social de la vivienda y a su consideración de necesidad de índole colectiva, frente a la cual el Estado no puede mantenerse indiferente y seguir pretendiendo que los ciudadanos deban, con carácter absoluto, autosatisfacer sus necesidades de vivienda conforme a sus posibilidades económicas en el mercado».

11 Cfr. AA. VV. Curso de Urbanismo, CEF, Madrid, 2006, vol. I, unidad 1, pág. 12. 
La materialización de dicho principio rector ha sido asumida como competencia propia por muchas Comunidades Autónomas, contando con el refrendo legitimador de la Sentencia del Tribunal Constitucional número 170/1989, de 19 de octubre ${ }^{12}$. En su virtud, buena parte de las normas reguladoras de la vivienda corresponden a las Autonomías y, como clarifica la Sentencia del Tribunal Constitucional número 61/1997, de 20 de marzo $^{13}$, dictada en sendos recursos de inconstitucionalidad, queda básicamente restringida la potestad normativa del Estado a los principios esenciales del estatuto de la propiedad (inmobiliaria) ${ }^{14}$. Consecuentemente, en el ejercicio de sus competencias, varias Comunidades autónomas han aprobado distintas normas incluyendo el concepto y calificación de Vivienda de Protegida, sin que exista una definición homologable entre todas las previsiones reguladoras ${ }^{15}$.

12 «(...) La legislación básica posee la característica técnica de normas mínimas de protección que permiten «normas adicionales» o un plus de protección; es decir, la legislación básica del Estado no cumple en este caso una función de uniformidad relativa, sino más bien de ordenación mediante mínimos que han de respetarse en todo caso, pero que pueden permitir que cada una de las Comunidades autónomas, con competencia en la materia, establezcan niveles de protección más altos que no entrarían por sólo eso en contradicción con la normativa básica del Estado».

${ }_{13}$ «En relación precisamente con el derecho a la propiedad que reconoce el artículo 33 C.E., hemos señalado que el título del artículo 149.1.1. C.E. no habilita para establecer una regulación uniforme de la propiedad privada, y su función social ni esa pretendida uniformidad puede servir de pretexto para anular las competencias legislativas que las Comunidades autónomas tienen sobre todas aquellas materias en las que entre en juego la propiedad (STC 37/1987). Al Estado le corresponde ciertamente establecer la regulación del contenido básico y primario del derecho de propiedad, en la medida en que afecte a las condiciones básicas de su ejercicio, pero el referido título competencial no habilita por sí mismo para que el Estado pueda regular cualquier circunstancia que, de forma más o menos directa, pueda incidir sobre la igualdad en el ejercicio del derecho. El propio tenor literal del precepto deja claro que la igualdad que se persigue no es la identidad de las situaciones jurídicas de todos los ciudadanos en cualquier zona del territorio nacional (lo que por otra parte sería incompatible con la opción por un Estado organizado en la forma establecida en el Título VIII de la Constitución), sino la que queda garantizada con el establecimiento de las condiciones básicas, que, por tanto, establecen un mínimo común denominador y cuya regulación, ésta sí, es competencia del Estado».

14 Cfr. AA.VV., Máster en dirección y gestión integral de empresas inmobiliarias y de la construcción. UNED, Madrid, 2007, Módulos IV y VI, pág. 85.

15 En el conjunto del Estado existieron básicamente tres opciones en cuanto a la calificación de las Viviendas Protegidas: Las Comunidades autónomas que optaron por la calificación definitiva o cuasi-definitiva. La primera fue la Comunidad Autónoma del País Vasco en el año 2002 y después le siguieron Catalunya (90 años), Extremadura (permanente) y Asturias (vida útil de la vivienda) todas ellas en el año 2004. Las Comunidades autónomas que mantuvieron, para sus propias tipologías autonómicas de Vivienda Protegida, más o menos, en el nivel marcado por el Plan Estatal 2005-2009 para favorecer el acceso de los ciudadanos a la vivienda (30 años, susceptibles de ampliación por las Comunidades autónomas). Las Comunidades 
Los planes estatales y autonómicos relativos a vivienda y suelo establecen unos requisitos determinados para que las edificaciones sean acreedoras de la calificación de Vivienda Protegida ${ }^{16}$. Algunas leyes, además, establecen el derecho de tanteo y retracto ${ }^{17}$ en favor de la Administración, a saber, el caso del País Vasco (Ley 7/1988, de 15 de abril), Galicia (arts. 35 a 37 de la Ley 4/2003, de 29 de julio), Cataluña (arts. 78.4 y 87 a 91 de la ley 18/2007, de 28 de diciembre) y la Ley 9/2001 de 17 de julio, del Suelo de la Comunidad de Madrid [art. 182.1.b) y la consecuente Orden 2.907/2005, de 23 de septiembre, de la Consejería de Medio Ambiente y Ordenación del Territorio].

La existencia de tal derecho de tanteo o retracto, supone que para la transmisión de viviendas protegidas (y al margen de la primera transmisión ${ }^{18}$ ) por el precio administrativo o determinado por módulo, procede solicitar autorización de venta a la Administración correspondiente.

No obstante, en la Comunidad de Madrid y en relación a la temática que nos ocupa, no es necesario solicitar autorización de venta ${ }^{19}$, siempre y cuando la vivienda sea adjudicada a uno de los cónyuges o comuneros, respectivamente:

a) Si hay disolución de la sociedad de gananciales matrimonial.

b) Si hay extinción de condominio.

A mayor abundamiento y para ser riguroso, también habría que hacer una mínima referencia al derecho de tanteo y retracto que pueden establecer los municipios sobre las viviendas protegidas que puedan promover. A título ilustrativo, cabe citar las limitaciones de disponer previstas en el artículo 25 del Reglamento de adjudicación de viviendas con protección pública afectas a los programas munici-

autónomas que, a través de diferentes tipologías autonómicas de Vivienda Protegida redujeron el periodo de calificación de las mismas. Destacan en este campo las Vivienda de Protección Pública destinadas al alquiler con opción de compra de la Comunidad Autónoma de Madrid descalificable a los siete años, pero también debemos citar las Vivienda Protegida autonómica descalificable a los quince años en Andalucía, Cantabria o Valencia y las Viviendas de Precio Tasado descalificables a los diez años en las Islas Baleares o Castilla-La Mancha.

16 Dichos requisitos son, por ejemplo: la superficie limitada; el precio tasado; el sorteo como vía de acceso a su titularidad y, finalmente, el control de la Administración sobre su disponibilidad.

17 Se trata de un derecho preferente de adquisición sobre la vivienda.

18 Es decir, cuando sea la venta o la adjudicación en propiedad por el promotor al adquiriente o adjudicatario.

${ }_{19}$ Como hemos visto, origen para que la Administración autonómica pueda ejercitar el derecho de tanteo o retracto. 
pales de vivienda a aplicar por la Empresa Municipal de la Vivienda y Suelo de Madrid, S.A., de 30 de octubre de 2012.

En resumen, estas características específicas distinguen las viviendas de protección de las que se hallan en el mercado libre inmobiliario.

Otro caso que reviste especial transcendencia es el de las viviendas que, si originariamente tenían limitadas las facultades de disposición dada su calificación de viviendas protegidas, en un plazo más o menos largo, se transformen en viviendas libres. O también, por haberse tramitado lo que se denomina la descalificación, consistente en la extinción del régimen dadas las específicas características de la vivienda.

En este punto, las diferentes legislaciones autonómicas vigentes tienen, a su vez ${ }^{20}$, normas en materia de dicha «descalificación». Es el caso del artículo 9 del Decreto 315/2002, de 30 diciembre de régimen de Vivienda de Protección Oficial y medidas financieras en materia de vivienda y suelo de Euskadi, donde se establece que las «viviendas que hayan sido objeto de calificación definitiva con arreglo a lo previsto en el presente Decreto, mantendrán permanentemente la misma, y por lo tanto, su naturaleza de protección oficial» ${ }^{21}$. Por su parte, Cataluña, en el artículo 78.5 de la Ley 18/2007, de 28 de diciembre, del derecho a la vivienda, se prohíbe la descalificación por interés del propietario, pero no la excluye "por razones de interés público vinculadas a las necesidades de la vivienda».

El Estatuto de Autonomía de la Comunidad de Madrid ${ }^{22}$ establece como competencia exclusiva la ordenación del territorio, urbanismo y vivienda. Competencia transferida a la Comunidad de Madrid en virtud del Real Decreto 1115/1984, de 6 de junio, sobre traspaso de funciones y servicios de la Administración del Estado a la Comunidad de Madrid en materia de patrimonio arquitectónico, control de la calidad de la edificación y vivienda.

En particular, la Ley 9/2001, del Suelo de la Comunidad de Madrid $^{23}$ es el marco normativo que tiene por objeto la ordenación urba-

$20 \mathrm{Al}$ igual que ocurre con la definición del concepto de las viviendas objeto de protección.

21 Contemplando un régimen transitorio en la Disposición transitoria primera, punto 2, para las viviendas construidas con anterioridad al Decreto.

22 Ley Orgánica 3/1983, de 25 de febrero, Estatuto de Autonomía de la Comunidad de Madrid, modificado por Ley Orgánica 5/1998, de 7 de julio, de reforma de la Ley Orgánica 3/1983.

23 Modificada por Ley 2/2005, de 12 de abril, de modificación de la Ley 9/2001, del Suelo de la Comunidad de Madrid. 
nística del suelo. El Título IV regula la intervención en el uso del suelo, en la edificación y en el mercado inmobiliario. El texto de la Ley regla la parcelación en las diversas clases de suelo y contempla las distintas modalidades de intervención de la Comunidad de Madrid, diferenciando las calificaciones urbanísticas y los proyectos de actuación especial. Por otra parte, también prevé la intervención de los Ayuntamientos en actos de uso del suelo, construcción y edificación.

Especial consideración merece la previsión que efectúa la Ley en relación con las viviendas sometidas a algún régimen de protección pública. Así, se ha fijado la cautela de exigir, por los Ayuntamientos la calificación provisional en el acto de solicitud de la preceptiva licencia urbanística y de la calificación definitiva, en la licencia de primera ocupación ${ }^{24}$.

De igual modo, respecto de este tipo de viviendas, se introduce la posibilidad de que la Comunidad de Madrid pueda ejercer los derechos de tanteo y retracto tanto sobre el suelo cuyo destino, según el planeamiento, sea la construcción de viviendas en régimen de protección, como sobre las propias viviendas sometidas a este régimen.

Las denominadas como Viviendas de Protección Oficial ${ }^{25}$ son, en puridad, las viviendas promovidas al amparo del Real Decreto-Ley 31/1978, de 31 de octubre, sobre política de viviendas de protección oficial. A partir del Reglamento que lo desarrolla ${ }^{26}$, se dictan normas estatales para el fomento de las VPO, a través de planes trienales o cuatrienales, aprobados por decretos. Todos los planes anteriores al vigente en cada momento se derogan, sin perjuicio de las situaciones creadas a su amparo.

Con la publicación del Real Decreto 2.190/1995, de 28 de diciembre, sobre Medidas de financiación de actuaciones protegibles en materia de Vivienda y Suelo para el período 1996-1999, se determinó que las ayudas reguladas por el Estado fueran gestionadas y ejecutadas por las Comunidades autónomas. Es decir, que el reconocimiento del derecho a las ayudas económicas financiadas con fondos estatales, debía hacerse por las Comunidades autónomas de conformidad a su propia normativa.

Por ello, la aplicación y desarrollo de los planes estatales se efectúa mediante convenios de colaboración entre el Ministerio encargado de la competencia en materia de vivienda y las Comunidades

24 LPO.

25 VPO.

26 Aprobado por Real Decreto 3148/1978, de 10 de noviembre, por el que se desarrolla el Real Decreto-ley 31/1978, de 31 de octubre, sobre política de vivienda. 
autónomas. Estas últimas pueden mejorar y completar, a través de su ordenamiento, las condiciones generales que fija el plan.

Mediante el Decreto 74/2009, de 30 de julio, del Consejo de Gobierno, por el que se aprueba el Reglamento de Viviendas con Protección Pública de la Comunidad de Madrid ${ }^{27}$, se regula el concepto y régimen jurídico de la denominada Vivienda con Protección Públi$\mathrm{ca}^{28}$. Así queda desvinculado del sistema de financiación cualificada de la misma, que pueda establecerse en el marco de cada Plan de vivienda de la Comunidad de Madrid o en cada Plan estatal de vivienda y suelo, que podrá variar ${ }^{29}$, sin afectar a dicho régimen jurídico.

Por tanto, el Reglamento de viviendas protegidas regula las diferentes tipologías de Vivienda con Protección Pública, estableciendo su régimen jurídico, es decir, sus características, los derechos y obligaciones a los que se ven sometidos los titulares o arrendatarios de este tipo de viviendas en la Comunidad de Madrid.

Podemos distinguir en dicho reglamento entre vivienda protegida estatal y vivienda protegida promovida con recursos de la Comunidad de Madrid. Pero, el Decreto 11/2005, de 27 de enero, por el que se aprobó el Reglamento de Viviendas con Protección Pública de la Comunidad de Madrid, extiende el mismo régimen jurídico de las Viviendas con Protección Pública a las Viviendas de Protección Oficial, ya sean de promoción privada o de promoción pública, promovidas en la Comunidad de Madrid, así como a las Viviendas con Protección Pública calificadas al amparo de decretos anteriores.

Efectivamente, la Disposición Transitoria Primera del Decreto $11 / 2005$, que sigue vigente, somete a las viviendas calificadas por decretos anteriores al régimen de protección pública establecido en el Reglamento de Viviendas con Protección Pública de la Comunidad de Madrid; sin otras excepciones que el plazo de duración de dichos regímenes, así como el porcentaje a aplicar para la determinación de las rentas máximas iniciales anuales de las viviendas destinadas a arrendamiento ${ }^{30}$.

La duración del régimen legal de protección de las Viviendas con Protección Pública para venta o uso propio, calificadas definitiva-

27 Deroga al Decreto 11/2005, de 27 de enero, por el que se aprueba el Reglamento de Viviendas con Protección Pública de la Comunidad de Madrid, a excepción de lo dispuesto en la disposición transitoria primera.

28 VPP.

29 Incluso significativamente, en años sucesivos.

30 Que serán los establecidos en las respectivas calificaciones de acuerdo con lo dispuesto en la normativa indicada. 
mente con anterioridad a la entrada en vigor de aquel Decreto, varía en función de la normativa que los regula ${ }^{31}$.

En definitiva, las viviendas protegidas están sometidas a un régimen legal de protección durante un número determinado de años, que variará en función de la tipología de vivienda que se trate o, en el menor de los casos, dicha protección es para siempre. Durante este plazo de duración, los propietarios no pueden vender o transmitir la vivienda a un precio libre, sin embargo, sí podrán venderla ${ }^{32}$ a un precio máximo legal de venta.

Dicho precio máximo, de acuerdo al artículo 12 del Decreto 74/2009, será establecido, por metro cuadrado de superficie útil, para

31 Así, por ejemplo: Decreto 43/1997, 13 de marzo, por el que se regula el régimen jurídico de las ayudas en materia de viviendas con protección pública y rehabilitación con protección pública del plan de vivienda de la Comunidad de Madrid 1997-2000: Treinta años desde su calificación definitiva. Si se hubiera obtenido un Préstamo Cualificado, la duración será de quince años. Decreto 228/1998, de 30 de diciembre, por el que se regula el régimen jurídico de las ayudas en materia de viviendas con protección pública y rehabilitación con protección pública del Plan de Vivienda de la Comunidad de Madrid 1997-2000: Treinta años desde su calificación definitiva. Si se hubiera obtenido un Préstamo Cualificado, la duración será de veinte años. Decreto 11/2001, de 25 enero, de la Consejería de Obras Públicas, Urbanismo y Transportes sobre financiación cualificada a actuaciones protegidas en materia de vivienda y su régimen jurídico para el período 2001-2004: Veinticinco años desde su calificación definitiva. Si se hubiera obtenido un Préstamo Cualificado, la duración será de veinte años. La duración del régimen legal de protección de las Viviendas con Protección Pública para Arrendamiento (VPPA), las Viviendas con Protección Pública para Jóvenes y Mayores (VPPJYM) y las Viviendas de Integración Social (VIS) cualquiera que sea el Decreto al amparo del cual se calificaron es el siguiente: Veinticinco años desde su calificación definitiva. Si se hubiera obtenido un Préstamo Cualificado, la duración será de diez años. La duración del régimen legal de protección pública de las Viviendas de Protección Oficial, calificadas definitivamente al amparo del Real Decreto Ley 31/1978, de 31 de octubre, o a las que éste les sea de aplicación, es treinta años desde su calificación definitiva. La duración del régimen legal de protección pública de las Viviendas de Protección Oficial para arrendamiento, calificadas definitivamente al amparo del Real Decreto Ley 31/1978, de 31 de octubre, o a las que éste les sea de aplicación, es treinta años desde su calificación definitiva, si obtuvo la misma con anterioridad al 1 de enero de 1995, o veinticinco años, si fue $a$ posteriori. Si hubiese obtenido préstamo cualificado, será la misma que la del plazo inicial de amortización del préstamo, a contar desde la fecha de calificación definitiva. La duración del régimen legal de protección pública de las viviendas de Protección Oficial, calificadas definitivamente al amparo del Real Decreto 2.114/1968, de 24 de Julio 1968, por el que se aprueba el Reglamento para la aplicación de la Ley sobre Viviendas de Protección Oficial, texto refundido aprobado por Decretos 2.131/1963, de 24 de julio y 3.964/1964, de 3 de diciembre, es cincuenta años desde su calificación definitiva. Estas viviendas han quedado liberalizadas de precio de venta y alquiler, en virtud del artículo 1 del Real Decreto 727/1993, de 14 de mayo, sobre precio de las viviendas de protección oficial de promoción privada.

32 Con la correspondiente autorización. 
cada una de las localidades o ámbitos intraurbanos del territorio de la Comunidad de Madrid, mediante Orden de la Consejería competente en materia de vivienda; con las matizaciones de la Disposición Adicional Segunda, para Viviendas de Protección Oficial de promoción pública.

Los últimos precios máximos de venta de las Viviendas con Protección Pública Básica (VPPB) y de las Viviendas con Protección Pública de Precio Limitado (VPPL) han sido establecidos mediante Orden 116/2008, de 1 de abril de la Consejería de Vivienda, por la que se adecuan y adaptan los precios máximos de venta y arrendamiento de las viviendas con protección pública a lo dispuesto en el Real Decreto 801/2005, de 1 de julio, y su modificación por Real Decreto 14/2008, de 11 de enero.

Esta cuestión es de suma importancia en el tema objeto de este trabajo, pues al liquidar la sociedad de gananciales, el avalúo de la vivienda protegida vendría establecido por el meritado precio máximo legal de venta, por supuesto, si no consideramos -o no se pudiera- la posibilidad de su descalificación, dicha circunstancia exigiría una valoración distinta de dicha vivienda.

Por tanto, las viviendas protegidas en la Comunidad Autónoma de Madrid poseen un régimen legal de protección que se refiere a las características, requisitos y limitaciones a los que han de someterse. En particular:

- Están sujetas a unos límites máximos en cuanto a su superficie y precio de venta y de renta.

- Se deben destinar a domicilio habitual y permanente, sin que pueda tratarse de segunda residencia o dirigirse a cualquier otro uso.

- Para cualquier obra o reforma es necesario solicitar autorización a la Dirección General de Vivienda y Rehabilitación.

- Han de ajustarse a la normativa estatal y autonómica en materia de edificación y, además, debe cumplir con las normas técnicas de diseño y calidad específicas para las Viviendas con Protección Pública de la Comunidad de Madrid.

Los planes de vivienda suponen un conjunto de medidas de apoyo a los ciudadanos con la finalidad de facilitarles la solución de vivienda. Dentro de ellos, la actuación de la Administración autonómica en viviendas con protección pública se concreta en: controles técnicos, estableciendo los requisitos de acceso para los solicitantes, 
determinando la renta máxima y el precio máximo legal de venta y otorgando ayudas económicas.

Las viviendas son construidas y comercializadas por los promotores, sean éstos públicos o privados. Dichos promotores solicitan a la Dirección General de Vivienda y Rehabilitación la calificación provisional de las viviendas que promueven como vivienda con protección pública.

La calificación provisional es otorgada por la Consejería de Vivienda a un proyecto de ejecución de vivienda, con carácter provisional, previo a la terminación de las obras. Momento en el que se podrá solicitar y, en su caso, obtener la calificación definitiva, por la que se declara su protección pública y se establece su régimen legal. Por tanto, las viviendas adquieren su condición definitiva con la calificación del mismo adjetivo (definitiva) de vivienda con protección pública.

Por otro lado, los solicitantes de vivienda con protección pública deberán documentar el cumplimiento de los requisitos de acceso ante los promotores que, a su vez, habrán de documentarlo ante la Administración autonómica.

Tras la recentísima entrada en vigor, el 11 de abril 2013 y al día siguiente de su publicación, del Real Decreto 233/2013, de 5 de abril, por el que se regula el Plan Estatal de fomento del alquiler de viviendas, la rehabilitación edificatoria, y la regeneración y renovación urbanas, 2013-2016, es preciso destacar, a vuela pluma, algunas de sus novedades que atañen a nuestro estudio.

En efecto, los planes estatales que se han ido aprobando, eran continuistas y estaban centrados en un mismo objetivo: incentivar la promoción y la construcción de viviendas. Este modelo va a ser objeto de cambio con el nuevo Plan estatal, determinando un vuelco absoluto en sus objetivos. En su virtud, los ejes básicos de este Plan pasan a ser el fomento del alquiler y la rehabilitación, renovación y regeneración urbanas. También, incluye un Programa de ayuda al alquiler de vivienda.

Según la Disposición Adicional Cuarta del Plan de vivienda y con el objetivo de que se puedan comercializar lo antes posible, se podrá modificar la calificación provisional o definitiva de las VPO en venta, "procedentes de promociones de viviendas protegidas acogidas a financiación de los planes estatales de vivienda, como también vivienda protegida en alquiler». Pero, dicha recalificación «no legitimará la obtención de nuevas ayudas estatales». 
El Plan también permite que, durante el plazo máximo de tres años, se puedan descalificar las viviendas protegidas de nueva construcción o procedentes de la rehabilitación y destinadas a la venta, pero siempre que hayan transcurrido al menos seis meses desde su calificación definitiva, y concurran las siguientes condiciones, sin perjuicio de las que puedan determinar las Comunidades autónomas y ciudades de Ceuta y Melilla:

a) Que la VPO se haya intentado adjudicar sin éxito y tras quedarse desierto, como mínimo, un ochenta por ciento del total de las viviendas.

b) Hallarse situadas en un ámbito territorial específico en el que pueda acreditarse con datos objetivos y de manera fehaciente que existen suficientes viviendas procedentes de la promoción libre, de similares características, tamaño y precio, terminadas en los últimos dos años, y sin vender.

Además, este Plan de vivienda posibilita el cambio de calificación de la vivienda protegida en venta a vivienda protegida en alquiler y viceversa.

En cualquier caso, toda VPO que se descalifique tendrá que devolver las ayudas económicas estatales percibidas, es decir, ayudas, bonificaciones y exenciones tributarias.

Para realizar esta modificación, que deviene en recalificación o descalificación, es necesario comunicarlo al Ministerio de Fomento en el plazo máximo de 10 días y al Registro de la Propiedad.

\section{Sistema de descalificación, especialmente en la Comunidad de Madrid}

Como ya adelantamos, por «descalificación» de una vivienda protegida, ya sea vivienda con protección pública o vivienda de protección oficial de promoción privada, se entiende la extinción del régimen legal de protección pública por el cual se regía la vivienda en lo relativo a sus características, condiciones de uso, conservación y responsabilidades, ayudas económicas y fijación de precios máximos. Tras lo cual las viviendas pasan a ser, a todos los efectos, viviendas libres. Dicha situación se puede obtener por el transcurso del tiempo establecido de duración de su régimen legal o, en determinadas circunstancias, por solicitud del propietario de la vivienda. 
La descalificación supone, por tanto, la extinción del régimen legal de protección de las viviendas protegidas, de forma que éstas pasan a ser, como decimos, a todos los efectos, viviendas libres. Se puede producir, tal y como se ha adelantado, adicionalmente al transcurso de la duración de su régimen legal, por los motivos y circunstancias siguientes:

- Voluntariamente, por solicitud del propietario de la vivienda a la Dirección General de Vivienda y Rehabilitación, transcurrido un período mínimo legalmente establecido, con algunas excepciones: si se trata de viviendas de protección oficial de promoción pública calificadas definitivamente al amparo del Real Decreto-Ley 31/1978, de 31 de octubre, en el caso de viviendas de integración social ${ }^{33}$, o bien, viviendas con Protección Pública calificadas al amparo del Reglamento de Viviendas con Protección Pública de la Comunidad de Madrid, aprobado por Decreto 74/2009, de 30 de julio.

- Como consecuencia de sanción impuesta.

En la extinción voluntaria del régimen legal tenemos que distinguir según se trate de Vivienda con Protección Pública (VPP) y Vivienda de Protección Oficial (VPO) de promoción privada.

Para la descalificación de la vivienda debe haber transcurrido un mínimo de quince años desde la calificación definitiva ${ }^{34}$, o bien cinco años desde la calificación definitiva, si se trata de VPO de promoción privada acogida al Decreto 2.114/1968, de 24 de julio ${ }^{35}$.

Para ambos tipos de viviendas protegidas habrá que justificar el motivo por el que se solicita la descalificación y será requisito: no haber obtenido ayudas financieras al amparo del Plan Estatal de Vivienda y Rehabilitación 2009-2012 aprobado en el Real Decreto 2.066/2008, de 12 de diciembre o del Plan Estatal de Vivienda 2005-2008 recogido en el Real Decreto 801/2005, de 1 de julio. Si se ha obtenido un préstamo cualificado al amparo de planes anteriores de vivienda, el préstamo cualificado habrá de haber sido amortizado o novado a uno libre, restituir las ayudas económicas y bonificaciones y/o exenciones tribu-

33 Vivienda de integración social o VIS Plan de vivienda 2005-08.

34 Art. 8 Reglamento de viviendas con protección pública, Decreto 11/2005.

35 Debemos tener en cuenta que estas VPO han quedado liberalizadas de precio de venta y alquiler por Real Decreto 727/1993, de 14 de mayo, por el que se regulan los precios de venta, en segundas y posteriores transmisiones, de las viviendas acogidas a los distintos regímenes de protección oficial de promoción privada, así como las rentas de dichas viviendas y su revisión. 
$\operatorname{tarias}^{36}$, con los intereses legales correspondientes. La Administración concederá la descalificación siempre que no se deriven perjuicios para terceros o el interés social.

Para las viviendas con protección pública, además, para el caso de que se hubiera disfrutado de un derecho de superficie o suelo gratuito, habrá de restituir a la Administración aportante un importe equivalente a la mitad del precio legal de la vivienda en el momento de la descalificación. No podrá ser descalificada la vivienda si está ocupada por un inquilino en régimen de arrendamiento. Tampoco si se hubiera obtenido un préstamo convenido ${ }^{37}$, en cuyo caso el régimen legal se extenderá a treinta años, dentro de los cuales no cabrá la descalificación voluntaria.

\begin{tabular}{|l|}
\hline Cuadro resumen del coste de la descalificación \\
\hline Devolución de la cuantía del préstamo pendiente de amortizar \\
\hline Posible comisión (penalización) por cancelación anticipada del préstamo \\
\hline Devolución de la cuantía de la subsidiación \\
\hline Impuesto AJD de la escritura de cancelación del préstamo \\
\hline Gastos de notario, registro, gestoría \\
\hline Devolución de bonificaciones tributarias (AJD e IVA o TP) \\
\hline Tasa $^{38}$ por descalificación \\
\hline
\end{tabular}

\section{VALORACIÓN DE LA VIVIENDA DE PROTECCIÓN OFICIAL EN LA LIQUIDACIÓN DE UNA SOCIEDAD DE GANANCIALES: EVOLUCIÓN JURISPRUDENCIAL}

Retomamos la pregunta capital que vertebra el presente trabajo: ¿Cuál es el valor que hay que dar a dicha vivienda protegida? Este

36 Actos Jurídicos Documentados e IVA o Trasmisiones Patrimoniales. Cfr. Real Decreto Legislativo 1/1993, de 24 de septiembre, por el que se aprueba el Texto refundido de la Ley del Impuesto sobre Transmisiones Patrimoniales y Actos Jurídicos Documentados y Ley 37/1992, de 28 de diciembre, del Impuesto sobre el Valor Añadido (últimas actualizaciones, en el momento de redactar estas líneas, para ambas leyes del 28 de diciembre de 2012).

37 Previsto en el Real Decreto 801/2005, de 1 de julio, por el que se aprueba el Plan Estatal 2005-2008, para favorecer el acceso de los ciudadanos a la vivienda.

38 Para iniciar la tramitación de la descalificación de vivienda protegida, es imprescindible acompañar al formulario, la documentación necesaria junto con el Ejemplar para la Administración del modelo 030 de la Tasa 7803 una vez que ésta haya sido abonada. El Decreto Legislativo 1/2002, de 24 de octubre, por el que se aprueba el Texto Refundido de la Ley de Tasas y Precios Públicos de la Comunidad de Madrid, establece que la cuantía que se ha de abonar por esta actuación es de $55,03 €$. 
valor ¿podrá ser el valor máximo de venta que tenga fijado administrativamente o el valor de mercado? ${ }^{39}$

La respuesta de la más reciente jurisprudencia del Tribunal Supremo fruto de la Sentencia 4 de abril de 2008 se inclina por imputarle el valor de mercado. Por las razones ya señaladas dirigidas a una liquidación de gananciales equilibrada y que permita una asignación de lotes equitativos para ambos ex-cónyuges. De lo contrario, si se aplicara el precio administrativo y se adjudicase a uno solo de los cónyuges, podría producirse un desequilibrio por la diferencia entre el valor administrativo y el potencial valor de mercado.

Antes de abordar el cambio jurisprudencia, vamos a transcribir a continuación un extracto de la Sentencia del Tribunal Supremo de 14 de noviembre de 2002 donde se recoge esta doctrina (modificada al tiempo por la STS de 2008):

«SEGUNDO. Todo el tema a dilucidar en este recurso de casación radica en determinar el valor que ha de asignarse a dos viviendas de protección oficial que forman parte de la sociedad de gananciales, pues según el valor que se les asigne se estimará la demanda y rechazará la reconvención o viceversa. Los órganos de instancia -Juzgado y Audiencia Provincial- han mantenido el criterio de seguir el valor asignado como viviendas de protección oficial, dejando de lado el valor real, cuyo avalúo se ha realizado en la prueba pericial de segunda instancia.

"Ciertamente la solución adoptada en la instancia, especialmente en la Sentencia de apelación se apoyó en la Sentencia de este Tribunal, con cita de otras, Sentencia n. ${ }^{\circ} 69$ de 9 de febrero de 1995- en que se sostiene que 'la doctrina de esta Sala en orden a la observancia de los precios establecidas por la normativa vigente en materia de Viviendas de Protección Oficial es constante y reiterada...'. Pero tal resolución recoge en su mismo fundamento de Derecho quinto apartado e)" que existen Sentencias favorables a la validez del contrato en que se pactan intereses superiores (Sentencias de 3 de septiembre y 14 de octubre de 1992), las mismas vienen referidas, cual se ha indicado en el fundamento tercero, a los supuestos de contratos de compraventa de dichos pisos y con base en una serie de consideraciones aquí no aplicables.

"Sin embargo, la Sentencia del mismo año, pero posterior, en concreto la 710, de 11 de julio de 1995, referida precisamente a un

39 Cfr. Rubio Torrano, Enrique, «Liquidación de gananciales y valor de la VPO», Aranzadi Civil, 2, 2008, págs. 2.285 a 2.287. 
tema sobre bienes de sociedad de gananciales y, por tanto, harto semejante al planteado en este recurso, dice en su fundamento jurídico cuarto: la parte no está conforme con la valoración dada al piso en cuestión que está calificado como vivienda de protección oficial, sin reparos que, en ocasiones, el valor real de un bien, no coincide con su precio autorizado, en este caso por limitaciones de orden administrativo. La posibilidad, sin embargo, de la descalificación, con las consecuencias legales inherentes a la misma, no puede razonablemente desconocerse y con ello, tampoco puede ignorarse que el precio entonces en el mercado sería notablemente mayor al autorizado. No se incurre, por tanto, en ningún acto o norma imperativa que conduzca a una nulidad de pleno derecho, en tanto que sólo se previenen las consecuencias de una posible descalificación y su repercusión sobre el valor real, y entonces libre del inmueble. La nueva jurisprudencia, además, ha venido a matizar los criterios anteriores respecto de las consecuencias de la venta de una Vivienda de Protección Oficial por encima de la cuantía de los precios máximos de venta que, aunque se traduzcan en la imposición de sanciones administrativas, no afecta a la validez de los contratos celebrados (Sentencia del T.S. de 4 de junio de 1993)."

"En igual sentido, la Sentencia núm. 1.073 de 16 de diciembre de 1995, también referida a un supuesto de sociedad de gananciales en su fundamento jurídico quinto señala en el apartado $1 .^{\circ}: 1^{\circ}$ ) Que siendo la única discrepancia la relativa a la adjudicación y valoración del inmueble actualmente disfrutado por resolución judicial como vivienda familiar por la esposa, es claro, que la pretensión de ésta según su 'petitum' y por las razones que aduce de su actual derecho de uso de la vivienda, de que se le adjudique la propiedad de la misma -apartado E, de su petitum-, habiendo de compensar al marido a tenor de la valoración de dicha vivienda en el importe de 1.323.509 ptas., como valor máximo según el Régimen de Viviendas de Protección Oficial, en el 50 por ciento de esta suma, es una petición a todas luces que vulnera el específico módulo de igualdad del citado artículo 1.061, ya que es evidente se elude crasamente ese mandato con pretendida adjudicación, pues sería hasta superfluo resaltar que, por razones de mercado, el precio y, sobre todo el valor real de la vivienda es muy superior al que postula la actora.

“Asimismo, se añade en el apartado siguiente: ' $2 .^{\circ}$ ) Con independencia de cuál sea el tratamiento de las viviendas sometidas al Régimen Especial y el carácter más o menos vinculantes de sus previsiones, no se ignora -como se especifica en la impugnación del recurso-, que tales sanciones se refieren, entre otras, a tenor de lo 
dispuesto en los artículos 28 y 29 del R.D. 2960/76, a prohibir expresamente el percibo de cualquier sobreprecio sobre el precio máximo fijado (sin que sea menester ahora reflexionar sobre el grado de eficacia sustantiva de esta prohibición, dentro de las relaciones intersubjetivas, al no ser tema decidendi), y que, en el caso de autos, no se está, pues, en el supuesto de hecho de que se trate de vender dicha vivienda, sino, estrictamente en el cómputo de su valor a efectos de que las adjudicaciones al esposo y a la esposa reflejen ese criterio legal de igualdad ${ }^{40}$."

"El parecido con el caso traído ahora a la censura casacional es tan evidente, en que existió reconvención y una doble valoración."

"Finalmente, la Sentencia 977/1996, de 21 de noviembre, que tenía su origen en una demanda que postulaba el derecho del actor a pedir la cesación del proindiviso de la vivienda objeto del litigio, disolviendo dicha comunidad de bienes y acordando su venta en pública subasta con admisión de licitadores extraños y en el reparto de la cantidad obtenida, se recoge en su único fundamento jurídico, impropiamente motejado de primero, con referencia a las viviendas de protección oficial, que 'están sometidas a unos precios máximos de adquisición, conforme a lo dispuesto en el Texto refundido aprobado por Real Decreto 2960/1976, de 12 de noviembre de 1976 (art. 28), Reglamento de 24 de julio de 1968 (arts. 112 y 127 -está modificado por Decreto 477/1972, de fecha 4 de marzo-) Real Decreto 31/1978, de 32 de octubre y Real Decreto 3148/1978, de 10 de noviembre (art. 11). Si bien el precio de adquisición permanece constante durante un año, a partir de la calificación se autoriza su actualización para las sucesivas transmisiones...'. Y más adelante: 'La legislación de las Viviendas de Protección Oficial no prohíbe sus transmisiones sucesivas y de producirse, aún rebasando los precios máximos, -lo que conviene decir que no conforma precisamente el objeto del debate y así lo entendió pero equivocadamente el Tribunal de instancia-. Estas ventas ulteriores no serían radicalmente nulas, y conforme ha declarado esta Sala de casación civil en Sentencias 15/2 y 24/6/1991, que decretan improcedente la nulidad total del negocio y sí la parcial de la obligación relativa de precio pactado con excesividad, conforme a la nueva doctrina (Sentencias de 3 de septiembre de 1992, 14 de octubre de 1992, 4 de junio de 1993, 21 de febrero de 1994 y 11 de julio de 1995) que resucita la que ya contenían las de 10 de febrero de 1966, 28 de abril de 1971, 20 de marzo de 1972 y 26 de mayo de 1974)

40 Es un principio constitucional la igualdad entre los cónyuges, como trasunto de la igualdad esencial de las personas, Cfr. LASARTE ÁLVAREZ, Carlos, Principios de Derecho Civil, VI. Derecho de familia, ed. Marcial Pons, Madrid, 2012, 11. ${ }^{a}$ ed., pág. 172. 
no afecta a la validez de las compraventas las celebradas con precios superiores a los oficiales, lo que sólo ocasiona infracción administrativa, con sanciones económicas y pérdidas de beneficios".

"A toda esta normativa, aún habría que añadir el Decreto de 10 de noviembre de 1978, el Real Decreto 1932/1991, de 20 de diciembre, el Real Decreto 726/1993, de 14 de mayo, así como las disposiciones dictadas por las respectivas Comunidades autónomas.

"En resumen, que la doctrina jurisprudencial va por camino diferente hoy que la instancia en ambas sentencias. La referencia del artículo $1.410^{41}$ del Código Civil a lo no previsto en el capítulo obliga a observar las reglas para la partición y liquidación de herencia, permite rescindir una liquidación que cause lesión en más de la cuarta parte $^{42}$. En este sentido, la Sentencia de esta Sala de 26 de enero de 1993 ha mantenido que ni tiene fundamento alguno la exclusión de la rescisión por lesión en la liquidación de la sociedad de gananciales, dada la genérica y omnicomprensiva remisión que efectúa el artículo 1.410 del Código Civil ${ }^{43}$.

41 Para la acción que se ejercita de rescisión por lesión, el art 1.410 del Cc, contiene una remisión expresa a las normas de partición de herencia, al establecer que «En todo lo no previsto en este capítulo sobre formación de inventario, reglas sobre tasación y ventas de bienes, división del caudal, adjudicaciones a los partícipes y demás que no se halle expresamente determinado, se observará lo establecido para la partición y liquidación de la herencia». Atendiendo a dicha remisión, el artículo 1.074 dispone que «Podrán también ser rescindidas las particiones por causa de lesión en más de la cuarta parte, atendido al valor de las cosas cuando fueron adjudicadas».

42 Se refiere a la acción rescisoria por lesión patrimonial, conocida en la práctica forense como «lesión de cuarta». En cuanto a la rescisión por lesión en más de la cuarta parte en las particiones efectuadas en la liquidación de la sociedad legal de gananciales: La Sentencia del Tribunal Supremo de 11 de junio de 1983 sale al paso de las dudas planteadas en la instancia acerca de la aplicación a la sociedad de gananciales del citado artículo 1.074; precepto que se estima aplicable no sólo por el carácter supletorio de las normas de la partición y liquidación de herencias, sino además por el juego del artículo 1.291 en su regla quinta que «hace referencia a cualquiera otros en que especialmente lo determine la ley, fórmula ésta dentro de la cual habrá necesariamente de encontrar acogida la rescindibilidad de las particiones hereditarias y de la sociedad de gananciales en los casos de lesión de más de la cuarta parte, a la que de manera especial y expresa, se refiere el artículo 1.074 del Código Civil». En la Sentencia de 26 de enero de 1993 se estima acreditada la existencia de lesión en cuantía superior a la cuarta parte del valor de los bienes adjudicados y a pesar de que la liquidación se había efectuado en convenio regulador que fue aprobado por el Juez, sin que tal resolución impida la posibilidad de impugnarla si se acredita la lesión; por ello se indica que «no tiene fundamento legal alguno la exclusión de la rescisión por lesión en la liquidación de la sociedad de gananciales, dada la genérica y omnicomprensiva remisión que el artículo 1.410 del C.C. efectúa, careciendo de base para negarle esa naturaleza de contrato oneroso que gratuitamente se atribuye a la liquidación practicada por los titulares ...».

43 Y procede la rescisión por lesión aunque derive de la liquidación de la sociedad de gananciales llevada a cabo por los cónyuges de común acuerdo, Cfr. SALAS 
"Se ha de procurar en la liquidación guardar en lo posible la igualdad, haciendo lotes o adjudicando a cada uno de los coherederos cosas de la misma naturaleza, calidad o especie, según el artículo 1.061 referido a la partición de herencia, pero aplicable a la liquidación de la sociedad de gananciales. En tal supuesto, se hace preciso evitar que una calificación jurídica diferente, viviendas de protección oficial y otras viviendas, pueda determinar distorsiones en esta igualdad que se pretende y el motivo debe ser acogido, con los efectos que se determinarán en el último fundamento jurídico de esta resolución.

TERCERO. El acogimiento del motivo único determina la revocación de la Sentencia recurrida en el sólo y exclusivo sentido de valorarse las viviendas y otros inmuebles de protección Oficial con el precio de mercado, pero referido al año 1989, año en que recayó Sentencia firme que acordó la separación conyugal y disuelta la sociedad de gananciales, haciendo la división y formación de los lotes de acuerdo con estas bases: a) Valoración en el precio del año 1989 y b) Tasación de los Inmuebles de Protección Oficial por el precio de mercado ${ }^{44}$ con tales características y referida al citado año 1989. c) Se tomará en cuenta asimismo la pericia practicada en el trámite de apelación y d) Se determinará sobre estas bases en periodo de ejecución de Sentencia».

Como sabemos el valor (real o administrativamente asignado) que debe atribuirse a una vivienda de protección oficial a la hora de proceder a su inventario y subsiguiente liquidación, no ha sido pacífico en la jurisprudencia y, en ocasiones como ya hemos apuntado, se ha relacionado indebidamente con el alcance de la prohibición de su venta y las consecuencias que de ella cabe derivar: nulidad absoluta, nulidad parcial, sanción puramente administrativa, etc.

Si se hace un repaso de algunas Sentencias dictadas por el Tribunal Supremo en esta materia ${ }^{45}$, fácilmente se concluye que hasta la Sentencia del Tribunal Supremo de 4 de abril de 2008, no parece existir un criterio firme y seguro sobre esta cuestión. Así, la cuestión debatida que dio lugar a la Sentencia del Tribunal Supremo de 9 de febrero de 1995 consistió en determinar si el valor del piso en cuestión era el que le atribuían los peritos informantes -entre cinco millones trescientas veinte mil y seis millones de pesetas- y mantenía

CARCELLER, Antonio, «Rescisión por lesión y liquidación de sociedad de gananciales», Repertorio de Jurisprudencia, 6, 2004, págs. 303 a 305.

44 El uso de negrita es propio.

45 Compárense las SSTS de 9 de febrero de 1995, 11 de julio de 1995, 14 de noviembre de 2002 y la más actual, de 4 de abril de 2008. 
el actor-recurrido, o el catastral -seiscientas veintitrés mil pesetascomo defendía la demandada recurrente, ya que el valor de compra del mismo como Vivienda de Protección Oficial fue de quinientas setenta y seis mil pesetas. La Sentencia de instancia, así como la de apelación, resolvió la cuestión optando por el precio fijado pericialmente.

El Tribunal Supremo, en la Sentencia referida del año 1995, después de señalar que lo único que puede ser acogido en el caso de la valoración de estos bienes en la liquidación de gananciales es que el requisito del precio cierto de estos pisos lo establece la disposición legal que los autoriza y determina, concluye estimando el motivo, dado que: «a) Nos hallamos a presencia de la liquidación de una sociedad de gananciales, en cuya operación es fundamental determinar el valor de su bien principal, el piso que ha motivado este proceso. b) Dicho inmueble está sujeto a la legislación de viviendas de protección oficial, ya que así fue adquirido. c) Habiendo sido hecha la calificación definitiva del mismo el 31 de mayo de 1971, conforme a lo dispuesto en el artículo 1. ${ }^{\circ}$ III del Real Decreto-ley 31/1978, de 31 de octubre (RCL 1978, 2419), sobre Política de Viviendas de Protección Oficial, el régimen legal de dichas viviendas se mantiene durante 30 años, lo que implica que en el presente momento sigue vigente. d) La doctrina de esta Sala en orden a la observancia de los precios establecidos por la normativa vigente en materia de viviendas de protección oficial $^{46}$ es, cual se ha expuesto, constante y reiterada. e) Si bien existen Sentencias favorables a la validez del contrato en que se pactan precios superiores, las mismas vienen referidas, cual se ha indicado en el fundamento tercero, a los supuestos de contratos de compraventa de dichos pisos y con base en una serie de consideraciones aquí no aplicables».

La Sentencia del Tribunal Supremo de 11 de julio de 1995 cambia radicalmente de criterio y no da lugar al recurso de casación contra la Sentencia dictada por la Audiencia Provincial. «La parte no se conforma [dice la Sentencia] con la valoración dada al piso en cuestión que está calificado como Vivienda de Protección Oficial, sin reparar que, en ocasiones, el valor real de un bien, no coincide con su precio autorizado, en este caso, por limitaciones de orden administrativo. La posibilidad, sin embargo, de la descalificación, con las consecuencias legales inherentes a la misma, no puede razonablemente desconocerse y, con ello, tampoco puede ignorarse que el precio entonces en el mercado sería notablemente mayor

\footnotetext{
$46 \quad$ El uso de negrita es propio.
} 
al autorizado ${ }^{47}$. No se incurre, por tanto, en ningún acto contrario a norma imperativa que conduzca a una nulidad de pleno derecho, en tanto que sólo se previenen las consecuencias de una posible descalificación y su repercusión sobre el valor real, y entonces libre del inmueble. La nueva jurisprudencia, además, [concluye] ha venido a matizar los criterios anteriores respecto de la consecuencia de la venta de una Vivienda de Protección Oficial por encima de la cuantía de los precios máximos de venta, que, aunque se traduzcan en la imposición de sanciones administrativas, no afecta a la validez civil de los contratos celebrados».

Contrasta con la anterior, la Sentencia del Tribunal Supremo de 14 de noviembre de 2002, ya citada y también en un pleito sobre liquidación de sociedad de gananciales, que dice: «se ha de procurar en la liquidación guardar en lo posible la igualdad, haciendo lotes o adjudicando a cada uno de los coherederos cosas de la misma naturaleza, calidad o especie, según el art. 1.061 referido a la partición de herencia, pero aplicable a la liquidación de la sociedad de gananciales. En tal supuesto, se hace preciso evitar que una calificación jurídica diferente, viviendas de protección oficial y otras viviendas, pueda determinar distorsiones en esta igualdad que se pretende». Por tanto, se acogió el motivo único y se revocó la Sentencia recurrida: «en el solo y exclusivo sentido de valorarse las viviendas y otros inmuebles de protección oficial con el precio de mercado ${ }^{48}$, pero referido al año 1989, año en que recayó Sentencia firme que acordó la separación conyugal y disuelta la sociedad de gananciales».

Finalmente cabe reseñar la Sentencia del Tribunal Supremo de 4 de abril de 2008. El supuesto que da lugar a la Sentencia se enmarca dentro de las incidencias sobrevenidas como consecuencia de una separación conyugal y disolución del régimen económico, en particular las que provoca el cuaderno particional, no aceptado por los cónyuges. El Juzgado de $1 .^{\text {a }}$ Instancia e Instrucción, además de determinar los bienes que debían figurar en el activo y el pasivo de la sociedad a liquidar, consideró que el valor de la vivienda de protección oficial a tener en cuenta en la liquidación era el real o efectivo, es decir, el de mercado y no el establecido administrativamente. En lo relativo a las adjudicaciones solicitadas, atribuye la vivienda a la esposa y al hijo. La Audiencia revoca la Sentencia de instancia y declara que la valoración de la vivienda debía hacerse conforme al precio oficial y se la adjudicó al marido demandante.

47 Ídem.

48 Ídem. 
El Tribunal Supremo recoge sucintamente la doctrina dispar y vacilante del propio tribunal sobre la materia. A tal efecto, recuerda la práctica unanimidad de la Sala sobre la validez de los contratos de compraventa de viviendas de protección oficial por precio superior al tasado, en el sentido de que aquélla no se puede ver afectada por esta circunstancia, al margen de las sanciones administrativas que semejante comportamiento pueda acarrear. Nos parece de relevante importancia, si bien resulta obiter dicta ${ }^{49}$, la afirmación sobre las Sentencias que así se pronuncian «no pueden ser utilizadas para resolver el presente recurso, porque en ellas se trata de la validez de contratos de compraventa, cuestión distinta de la que debe resolverse ahora». La Sentencia trae a colación los criterios utilizados para adoptar la solución relativa a la valoración a precio de mercado, en particular: la temporalidad de las limitaciones a la libertad de disposición, la prohibición del enriquecimiento injusto y el respeto al régimen de igualdad.

Ante la situación de jurisprudencia no uniforme, pese a que se señaló día para votación y fallo del recurso del que dimana la meritada Sentencia del Tribunal Supremo, el acto fue suspendido, acordándose por resolución de la misma fecha que la Sentencia se dicte por el Pleno de los Magistrados de la Sala ${ }^{50}$, señalándose finalmente el 4 de abril de 2008 para su votación y fallo.

La Sentencia del Tribunal Supremo de 4 de abril de 2008, después de dejar constancia de que la legislación sobre estas viviendas es muy dispar, ya que buena parte de las competencias en la materia recae en las Comunidades autónomas, sienta la siguiente doctrina ${ }^{51}$ : para proceder a la valoración en la liquidación de los gananciales de las viviendas de protección oficial debe partirse de un dato imprescindible, cual es la posibilidad de que en un plazo determinado dicha vivienda deje de tener la condición de vivienda protegida y sea, por tanto, descalificada. A la vista de lo anterior, la Sentencia diferencia los supuestos de vivienda descalificable y no descalificable. El precio de esta última, será fijado acuerdo con el valor oficial. La vivienda descalificable (dice el Alto Tribunal) debe ser valorada de acuerdo con un criterio ponderado, porque en el momento de la disolución

49 Es el plural latín de obiter dictum, que es una consideración de derecho no estrictamente necesaria para sentenciar la causa, pero que un juez o tribunal incluyen en los considerandos porque quieren dar una decisión más completa.

50 El Pleno de los Magistrados de la Sala del Tribunal Supremo trata de unificar criterios en cuestiones jurídicas de importancia en las que no existe consenso en las distintas Sentencias del propio tribunal.

51 En nuestra modesta opinión, matizada y que podría consolidarse en el futuro, pero a la postre de difícil aplicación práctica. 
de la sociedad de gananciales, la vivienda no es de libre disposición, aunque debido a su naturaleza, lo será en el tiempo establecido en el concreto plan, que ambos cónyuges conocen.

Por tanto, «en los casos de vivienda descalificable se aplicará el valor del mercado en el momento de la extinción del régimen, rebajado en la proporción que resulte en relación al tiempo que falte para la extinción del régimen de protección». Lo cual supone, en definitiva, la complicación añadida de diferir la efectiva valoración de la vivienda a la fase de ejecución de la Sentencia ${ }^{52}$.

Pues bien, para PÉREZ UREÑA ${ }^{53}$ esta Sentencia del Tribunal Supremo de 4 de abril de 2008 es muy acertada ya que «en virtud de esta nueva doctrina, la VPO no descalificable debe ser valorada de acuerdo con el valor oficial y la descalificable de acuerdo con el valor de mercado rebajado en la proporción que resulte en relación al tiempo que falta para la extinción del régimen de protección. Esta doctrina da respuesta al supuesto, v.gr., de la vivienda que se halla afecta durante treinta años a las limitaciones de precio establecidas en la legislación de VPO, posibilitando su valoración conforme al valor de mercado, y sensu contrario será de aplicación sólo a aquellos supuestos en los que la vivienda tenga posibilidades de descalificación, sin distinguir entre las VPO de promoción privada y pública. Esta doctrina ha sido secundada inmediata y casi unánimemente por la jurisprudencia menor de las Audiencias Provinciales por lo que, con los matices expuestos, entendemos que la polémica existente hasta hace poco tiempo parece zanjada».

A nuestro juicio, sin embargo, la meritada Sentencia sienta un criterio ponderado, alejado de postulados maximalistas (puro valor de mercado o valor oficial) recogidos en Sentencias anteriores y pue-

52 «La valoración de la vivienda de protección oficial en la liquidación de gananciales, a la luz de la praxis judicial», Boletín Derecho de Familia, 1 de noviembre de 2012, www.elderecho.com/civil/valoracion-proteccion-liquidacion-ganancialesjudicial_11_478930007.html (fecha de consulta: 8 de junio de 2013). El autor recoge la Sentencia de la AP Sta. Cruz de Tenerife, Sec. 1. a , de 8 de abril de 2011 que establece: «[...] siendo pacífico que la vivienda de litis es descalificable, procede la estimación parcial de recurso para proceder como dictamina la jurisprudencia, de modo que el valor a tener en cuenta en la liquidación de la sociedad de gananciales de la vivienda de protección oficial es el valor del mercado del momento de la disolución de la sociedad de gananciales, rebajado en la proporción que resulte en relación al tiempo que falte para la extinción del régimen de protección, lo que se determinará en ejecución de sentencia, con la consiguiente repercusión en la distribución de lotes equitativos, conforme al resto de las valoraciones de bienes efectuadas, debiéndose practicar con su resultado, si resultare procedente, nueva distribución y adjudicación por el contador [...]».

53 Ibídem. 
de dar origen a una nueva jurisprudencia más matizada y acorde con los intereses en juego en este tipo de conflictos.

\section{OPCIÓN PERSONAL: IMPOSIBILIDAD DE UTILIZAR COMO CRITERIO EL ACOGIDO PARA LA VALIDEZ DE LOS CONTRATOS DE COMPRAVENTA CON SOBREPRECIO (CRITERIOS JURISPRUDENCIALES EN ESTA MATERIA), CRITERIO QUE SE PROPONE Y JUSTIFICACIÓN DEL MISMO}

Con motivo de la liquidación de las sociedades de gananciales y en conexión con el valor que deba de atribuirse a la vivienda protegida, resulta de máxima relevancia la respuesta que la jurisprudencia, previamente, ha dado a la cuestión relacionada de la validez de un contrato de compraventa de vivienda protegida, otorgado entre particulares y en el que se consigna un precio superior al establecido reglamentariamente.

Baste decir, que el Tribunal Supremo en sus sentencias más recientes (por ejemplo, la tan repetida Sentencia de 4 de abril de 2008) se ha pronunciado afirmativamente respecto a la validez de dichos contratos. No obstante, fija prístinamente que, en tales casos, procedería la aplicación de las sanciones administrativas correspondientes $^{54}$. Entre otras razones, el Alto Tribunal se pronuncia en este sentido para evitar el abuso de algunos compradores, que suscribían torticeramente contratos de compraventa a precio de mercado, para después instar judicialmente la pretensión de aplicar el precio administrativo según el módulo correspondiente.

Por consiguiente, lo cierto es que los meritados contratos de compraventa de vivienda protegida, celebrados entre particulares en los que se establezca un precio al alza respecto al fijado administrativamente, resultarán válidos y eficaces para las partes ${ }^{55}$. En buena lógica, al ex-cónyuge a quien se atribuya la vivienda protegida en la liquidación de la concreta sociedad de gananciales, podría ulteriormente vender dicha vivienda a un tercero a precio de mercado. La

54 ACEDO-RICO HENNING sostiene que en la venta de una vivienda protegida por un precio superior al máximo señalado en la calificación correspondiente, habrán de ser diferenciados los efectos administrativos de los efectos civiles en estos contratos, y respecto a estos últimos, concluye la plena eficacia civil de dichos contratos siempre y cuando la parte compradora sea consciente de que adquiere una VPO (vid., «La venta de VPO. Segunda transmisión. El RD 801/2005, de 1 de julio (I)», Boletín de Contratación Inmobiliaria El Derecho, 32, febrero de 2007.

55 Cfr. Sentencias del Tribunal Supremo de 3 de septiembre y 14 de octubre de 1992. 
hipótesis anterior parece que se acerca, a una suerte de enriquecimiento injusto de dicho ex-cónyuge, si bien mucho habría que decir sobre esta calificación, toda vez que cualquiera de los bienes de los que resulte adjudicatario uno $\mathrm{u}$ otro bien pueden ser vendidos con una sustancial ganancia o, por el contrario, transmitidos a un precio inferior al que le fueron asignados.

Ahora bien y a la vista del contenido del artículo 1.410 del Código Civil y la doctrina de la rescisión por lesión en más de una cuarta parte del valor real del bien, cabe cuestionarse si resultaría de aplicación al caso que nos ocupa. La referencia al artículo 1.410 del C.C. en lo no previsto en el capítulo relativo a la sociedad de gananciales, obliga a observar las reglas para la partición y liquidación de herencia, permitiendo rescindir una liquidación que cause lesión en más de la cuarta parte.

En este sentido, la Sentencia del Tribunal Supremo de 26 de enero de 1993, ha mantenido que carece de fundamento alguno la inaplicabilidad de la rescisión por lesión en los supuestos de liquidación de la sociedad de gananciales, en virtud del artículo 1.410 del Código Civil. Téngase en cuenta que, en el supuesto de autos se alegaba la infracción del ordenamiento, por inaplicación del artículo $1.074^{56}$ en relación con el mencionado artículo 1.410. En su defensa, se combate la resolución recurrida por cuanto ratificaba la inaplicabilidad de las normas de rescisión de las operaciones particionales a la liquidación de la sociedad de gananciales, al asimilarla a un contrato oneroso, y en el Código Civil la rescisión por lesión los excluye, al margen de lo prevenido en el artículo 1.291, 1 y 2 del Código Civil ${ }^{57}$.

56 Artículo 1.074 del C.C.: «Podrán también ser rescindidas las particiones por causa de lesión en más de la cuarta parte, atendido el valor de las cosas cuando fueron adjudicadas». Vid. PAZ-ARES RODRÍGUEZ, Cándido (et alia, dirigido) Comentario del Código Civil, Tomo I, Ministerio de Justicia, Madrid, 1993, pág. 2.516, 2. a ed.: «Como se ve, la rescisión por lesión en los contratos se admite en el CC solamente en casos excepcionales, a diferencia de lo que ocurre en algunas regiones de Derecho Civil especial. Por el contrario, en sede de partición la rescisión por lesión según el artículo 1.074 se admite con carácter general (luego veremos las excepciones reales o posibles) siempre que la lesión alcance más de la cuarta parte atendido el valor de las cosas que hubiesen sido adjudicadas. Esta diferencia de trato se explica si se tiene en cuenta que en los contratos por lo general las partes tienen intereses contrapuestos y, por consiguiente, cada una de las partes pretende obtener el máximo beneficio».

57 Artículo 1.291 del C.C.: «Son rescindibles: $1 .^{\circ}$ Los contratos que pudieren celebrar los tutores sin autorización judicial, siempre que las personas a quienes representan hayan sufrido lesión en más de la cuarta parte del valor de las cosas que hubieren sido objeto de aquéllos. La expresión «sin autorización judicial» contenida en el número $1 .^{\circ}$ del artículo 1.291 fue introducida por la LO 1/1996, 15 enero, de Protección Jurídica del Menor, en sustitución de la anterior «sin autorización del 
El Alto Tribunal concluye que «el motivo ha de ser acogido, pues no tiene fundamento legal alguno la exclusión de la rescisión por lesión en la liquidación de la sociedad de gananciales, dada la genérica y omnicomprensiva remisión que efectúa el artículo 1.410 del Código Civil, careciendo de base para negarla esa naturaleza de contrato oneroso que gratuitamente se atribuye a tal liquidación practicada por los titulares; lo mismo -siguiendo en esa vía analógica equivocada- se podría predicar de la partición de la herencia que practicasen los coherederos entre sí, y, sin embargo, el artículo 1.074 del Código Civil no la excepciona de su aplicación».

Por otro lado y en relación a lo que acabamos de exponer, nos podemos cuestionar, si sería de aplicación la doctrina del enriquecimiento injusto (o más propiamente, del enriquecimiento injustificado) caso de optar por la valoración oficial. La remisión legal operada ex artículo 1.410 al artículo $1.061^{58}$, como garante de la proporcionalidad en la liquidación de la sociedad de gananciales, es una suerte de lex specialis.

A mayor abundamiento, debemos tener presente que es doctrina jurisprudencial consolidada del Tribunal Supremo ${ }^{59}$, la inaplicabilidad de la regla prohibitiva del enriquecimiento injustificado cuando el presunto enriquecimiento lo ha sido en virtud de una disposición legal (que en el presente caso, sería la que determine el precio administrativo del inmueble protegido según el módulo correspondiente).

Pero vamos a retomar la cuestión que trataban de abordar los magistrados del Supremo, de si es válida una compraventa de Vivienda de Protección Oficial en la que se pacta un precio superior al que determina la Ley y, en su caso, cuáles son las consecuencias legales que se derivan del establecimiento de un sobreprecio. Al respecto, podemos afirmar que la regulación legal en esta materia está constituida por los artículos 11 y 51 del Real Decreto 3148/1978, de 10 de noviembre, por el que se desarrolla el Real Decreto-Ley 31/1978, de 31 de octubre, sobre política de vivienda (Reglamento de Viviendas de Protección Oficial), que ha sido objeto a lo largo del tiempo de diversas interpretaciones por nuestros tribunales. Históri-

consejo de familia». Finalmente el punto 2. ${ }^{\circ}$ del artículo 1.291 dice «Los celebrados en representación de los ausentes, siempre que éstos hayan sufrido la lesión a que se refiere el número anterior».

58 Artículo 1.061 del C.C.: «En la partición de la herencia se ha de guardar la posible igualdad, haciendo lotes o adjudicando a cada uno de los coherederos cosas de la misma naturaleza, calidad o especie».

59 Por ejemplo, SSTS de 30 de marzo de 1988, 23 de marzo de 1992 y 4 de marzo de 1997. 
camente, han sido mantenidas dos tesis diferentes en respuesta a la cuestión planteada.

Inicialmente, el Tribunal Supremo estimó la plena validez del contrato de compraventa desde el punto de vista civil, incluida la cláusula relativa al precio en la que se estipula un precio de venta superior al legalmente establecido ${ }^{60}$. Consideraba el Tribunal Supremo que la infracción de las disposiciones que establecían un precio máximo de venta en el caso de viviendas de protección oficial, producía efectos exclusivamente en el ámbito administrativo pero no en el civil.

La consecuencia práctica de esta primera tesis era que el contrato de compraventa resultaba válido en los términos pactados y obligaba a ambas partes en la totalidad de su clausulado, incluido el sobreprecio pactado. La infracción de la norma legal relativa al precio máximo de venta produciría efectos en la esfera administrativa, consistentes en la imposición de multas, descalificación de la vivienda como Vivienda de Protección Oficial e incluso, la obligación de devolver las cantidades percibidas indebidamente como sobreprecio.

En sentencias posteriores ${ }^{61}$, el Tribunal Supremo sostuvo la nulidad parcial del contrato de compraventa. Según esta otra corriente jurisprudencial, el contrato de compraventa era válido, pero no así la cláusula contractual relativa al precio en la que se establecía un precio de venta superior al legalmente permitido, que era nula. La nulidad parcial del contrato implicaba que el precio de venta superior al legalmente permitido quedaba sustituido, automáticamente, por el establecido por Ley, sin perjuicio de las sanciones administrativas procedentes.

Dicha tesis se sustentaba en que la determinación del precio en este tipo de compraventas queda fuera del principio de autonomía de la voluntad de las partes, habida cuenta de que el precio estaba previsto de forma imperativa por Ley. Se trataría, en consecuencia, de contratos normados en cuanto a uno de sus elementos esenciales como es el precio.

La consecuencia práctica de esta segunda tesis era la producción de dos efectos jurídicos diferentes:

a) en la esfera civil, el precio pactado superior al permitido quedaba sustituido por el precio establecido por Ley, de manera que el vendedor únicamente podía exigir el pago del precio establecido por Ley y no el acordado con el comprador;

60 Vid., por todas, las SSTS de 9 de febrero y 11 de julio de 1995.

61 SSTS de 14 de octubre de 1992, 21 de febrero de 1994 y 11 de julio de 1995. 
b) en la esfera administrativa, se impondrían las sanciones que establece la Ley para tales casos.

Últimamente, las tesis del Tribunal Supremo ${ }^{62}$ parecen volver a la de la validez del contrato de compraventa, sin perjuicio de la imposición de las sanciones previstas por las normas administrativas, en los términos expuestos anteriormente.

La dicción de la referida Sentencia del Tribunal Supremo, de 4 de abril de 2008, declara: «en los casos de vivienda descalificable se aplicará el valor del mercado en el momento de la extinción del régimen, rebajado en la proporción que resulte en relación al tiempo que falte para la extinción del régimen de protección» con lo que la solución al nudo gordiano del tema objeto de estudio, parece, cuando menos, poco clara. Porque, ¿qué índice aplicamos para valorar y determinar la rebaja en proporción al tiempo que falte para la extinción del régimen de protección?

Siguiendo el artículo de opinión de ZARRALUQUI SÁNCHEZEZNARRIAGA, «El bosque legislativo ${ }^{63}$ y haciendo un símil, parece que no sólo «el legislador oculta la ley», quizá también Tribunal Supremo no sea todo lo transparente que cabría exigir, pese al mérito de una resolución unificadora y alejada de maximalismos.

La anterior apreciación, nos lleva a hacer también una analogía con la normativa de la Comunidad Autónoma de Madrid sobre vivienda protegida ${ }^{64}$; en efecto, es una auténtica maraña normativa que a continuación sistematizaremos.

$\mathrm{Al}$ valorar una vivienda protegida sita en Madrid, la primera operación sería determinar si se puede descalificar o no. El derogado Reglamento, Decreto 11/2005, de 27 de enero, por el que se aprueba el Reglamento de Viviendas con Protección Pública de la Comunidad de Madrid, vigente hasta 11 de Agosto de 2009, permitía en su artículo 8 la descalificación voluntaria.

Sin embargo, el artículo 10.3 del vigente Reglamento, Decreto 74/2009, de 30 de julio, por el que se aprueba el Reglamento de Viviendas con Protección Pública de la Comunidad de Madrid, prohíbe la descalificación voluntaria de viviendas de la siguiente forma: «3. Las Viviendas con Protección Pública no podrán ser objeto de descalificación voluntaria, y las limitaciones que impone el régimen legal de

62 Por todas, la meritada Sentencia de 4 de abril de 2008.

63 Publicado en la revista Otrosí n. ${ }^{\circ} 1,4 .^{\text {a }}$ etapa.

64 En la cual se enfoca el presente trabajo sobre la valoración de la vivienda protegida con ocasión de la liquidación de la sociedad de gananciales. 
protección pública se extinguirán, quedando, en consecuencia, sometidas las viviendas al régimen general establecido en la legislación común, únicamente por el mero transcurso del plazo que corresponda de conformidad con lo dispuesto en el apartados anteriores, y sin que sea necesario ninguna declaración especial al efecto».

No obstante, hay que tener presente que la derogación normativa de los Reglamentos de viviendas con protección pública de la Comunidad de Madrid es sin perjuicio de su aplicación a aquellas viviendas calificadas a su amparo. Por consiguiente, no se podrán descalificar voluntariamente viviendas con Protección Pública calificadas al amparo del Reglamento de Viviendas con Protección Pública de la Comunidad de Madrid, aprobado por Decreto 74/2009, de 30 de julio, pero sí otras viviendas como hemos visto.

Para poder descalificar voluntariamente será preciso que haya transcurrido el plazo mínimo que establezca el Plan de Vivienda al que esté acogida. Normalmente quince años desde la calificación definitiva de la promoción o vivienda de que se trate, como establece el artículo $8^{65}$ del anterior Reglamento o Decreto 11/2005, de 27 de enero, para Vivienda con Protección Pública o bien, transcurridos cinco años para la no sujeción al régimen legal de protección si es una VPO acogida al Decreto 2114/1968, de 24 de julio. Asimismo que no se trate de una Vivienda de Integración Social ni Vivienda con Protección Pública calificada expresamente para arrendamiento, mientras mantenga dicho régimen de uso (art. 8 del Decreto 11/2005, de 27 de enero), o de una de Protección Oficial de promoción pública (D. A. Primera, punto 4, del Decreto 11/2005, de 27 de enero).

Si no podemos descalificar, hay que valorar según el precio máximo de venta (precio administrativo o según módulo). Conforme al artículo 12.2 del vigente Reglamento de viviendas con protección

65 El artículo 8.2 del Decreto 11/2005, de 27 de enero, establece: «El propietario de una Vivienda con Protección Pública podrá solicitar su descalificación durante la vigencia del régimen legal de protección, si ha transcurrido un mínimo de quince años desde la calificación definitiva, la cual se concederá por la Consejería competente en materia de vivienda, si de ella no se derivan perjuicios para terceros. Para obtener la descalificación, será necesario que el préstamo cualificado obtenido para la vivienda, en su caso, haya sido amortizado totalmente o haya sido novado previamente en un préstamo libre, y que el interesado haya restituido el importe de la totalidad de las ayudas económicas directas percibidas y, en su caso, el importe de las bonificaciones tributarias con sus intereses legales correspondientes en ambos casos. No podrán ser objeto de descalificación las Viviendas con Protección Pública calificadas expresamente para arrendamiento mientras mantengan dicho régimen de uso, ni las Viviendas de Integración Social. La descalificación como sanción se atendrá a lo dispuesto en el artículo 10.a) de la Ley 9/2003, de 26 de marzo, del Régimen Sancionador en Materia de Viviendas Protegidas de la Comunidad de Madrid». 
pública de la Comunidad de Madrid (Decreto 74/2009, de 30 de julio, por el que se aprueba el Reglamento de Viviendas con Protección Pública de la Comunidad de Madrid) el precio máximo legal de venta será establecido, por metro cuadrado de superficie útil, para cada una de las localidades o ámbitos intraurbanos del territorio de la Comunidad de Madrid, mediante orden de la Consejería competente en materia de vivienda. La última Orden es la 116/2008, de 1 de abril, que establece los precios máximos de venta (y arrendamiento) de las viviendas con protección pública.

En el cuadro siguiente se reflejan dichos precios máximos de venta para cada tipo de vivienda protegida en los distintos ámbitos.

\begin{tabular}{|l|c|c|c|c|}
\hline ZONAS & VPPB & VPPL & $\begin{array}{c}\text { VPO } \\
\text { Régimen } \\
\text { especial }\end{array}$ & $\begin{array}{c}\text { Adquisición } \\
\text { de VPO usada }\end{array}$ \\
\hline Zona A & $1.940,48 € / \mathrm{m}^{2}$ & $2.425,60 € / \mathrm{m}^{2}$ & $1.819,20 € / \mathrm{m}^{2}$ & $2.668,16 € / \mathrm{m}^{2}$ \\
\hline Zona B & $1.576,64 € / \mathrm{m}^{2}$ & $1.970,80 € / \mathrm{m}^{2}$ & $1.478,10 € / \mathrm{m}^{2}$ & $1.940,48 € / \mathrm{m}^{2}$ \\
\hline Zona $\mathrm{C}$ & $1.394,72 € / \mathrm{m}^{2}$ & $1.743,40 € / \mathrm{m}^{2}$ & $1.307,55 € / \mathrm{m}^{2}$ & $1.576,64 € / \mathrm{m}^{2}$ \\
\hline Zona D & $1.212,80 € / \mathrm{m}^{2}$ & $1.516,00 € / \mathrm{m}^{2}$ & $1.137,00 € / \mathrm{m}^{2}$ & $1.212,80 € / \mathrm{m}^{2}$ \\
\hline
\end{tabular}

Haciendo un ejercicio integrador de comparación y asimilando tipologías distintas de las Comunidades autónomas con las de Madrid, podemos observar en el cuadro inferior que los precios máximos de venta de Madrid están por encima de la media de las Comunidades autónomas en su conjunto.

\begin{tabular}{|c|c|c|c|c|}
\hline $\begin{array}{c}\text { CC.AA./ } \\
\text { Tipología }\end{array}$ & $\begin{array}{c}\text { VPO Régimen } \\
\text { General }\end{array}$ & $\begin{array}{c}\text { VPO Régimen } \\
\text { General }\end{array}$ & $\begin{array}{c}\text { VPO Régimen } \\
\text { Especial }\end{array}$ & $\begin{array}{c}\text { VPO Régimen } \\
\text { Especial }\end{array}$ \\
\hline $\begin{array}{c}\text { CC.AA./ } \\
\text { Zonas }\end{array}$ & Zona + cara & Zona + barata & Zona + cara & Zona +barata \\
\hline CAM & $1.940,48 € / \mathrm{m}^{2}$ & $1.212,80 € / \mathrm{m}^{2}$ & $1.819,20 € / \mathrm{m}^{2}$ & $1.137,00 € / \mathrm{m}^{2}$ \\
\hline $\begin{array}{c}\text { Media } \\
\text { CC.AA. }\end{array}$ & $1.495,30 € / \mathrm{m}^{2}$ & $1.171,14 € / \mathrm{m}^{2}$ & $1.319,03 € / \mathrm{m}^{2}$ & $1.032,14 € / \mathrm{m}^{2}$ \\
\hline
\end{tabular}

Por entender que existe una dificultad práctica para aplicar el método de valoración dimanante la nueva jurisprudencia del Tribunal Supremo antes comentada («se aplicará el valor del mercado en el momento de la extinción del régimen, rebajado en la proporción que resulte en relación al tiempo que falte para la extinción del régimen de protección»), en los casos de vivienda protegida descalificable, se propone que se valore a precio de mercado minorando todos los costes que genera dicha descalificación. 
A continuación se recoge un cuadro resumen de la valoración de la vivienda protegida descalificable según el método propuesto.

\section{CUADRO RESUMEN DE VALORACIÓN}

Valor de mercado de la vivienda: número de $\mathrm{m}^{2}$ útiles $\mathrm{x}$ precio medio de la zona de su situación $\left(€ / \mathrm{m}^{2}\right.$ útil)

Coste de la descalificación $(\mathrm{A}+\mathrm{B}+\mathrm{C}+\mathrm{D}+\mathrm{E}+\mathrm{F}+\mathrm{G})$

A) Devolución de la cuantía del préstamo pendiente de amortizar

B) Posible comisión (penalización) por cancelación anticipada del préstamo

C) Devolución de la cuantía de la subsidiación

D) Impuesto AJD de la escritura de cancelación del préstamo

E) Gastos de notario, registro, gestoría

F) Devolución de bonificaciones tributarias (AJD e IVA o TP)

G) Tasa por descalificación

Valor vivienda ${ }^{66}=$ Valor de mercado-Coste de descalificación

\section{BIBLIOGRAFÍA Y FUENTES CONSULTADAS}

AA. VV. Curso de Urbanismo, CEF, Madrid, 2006.

AA.VV. Máster en dirección y gestión integral de empresas inmobiliarias y de la construcción, UNED, Madrid, 2007.

ACEDO-RICO HENNING, Fernando, «La venta de VPO. Segunda transmisión. El RD 801/2005, de 1 de julio (I)», Boletín de Contratación Inmobiliaria El Derecho, 32, febrero de 2007.

BLANCO BAREA, José Ángel, Viviendas de Protección Oficial (VPO): tramitación administrativa y ayudas: normativa estatal y autonómica, Comares, Granada, 2004.

CALAZA LÓPEZ, María Sonia, «Principios rectores del proceso judicial español», RDUNED, 8, 2011, págs. 49 a 84 .

CASTRO MARTÍN, Rosa María, El Derecho de familia ante los nuevos retos legales, Dykinson, Madrid, 2013, 1. ${ }^{\text {a }}$ ed.

DIRECCIÓN GENERAL DE VIVIENDA. CONSEJERÍA DE VIVIENDA. COMUNIDAD DE MADRID, Compendio de Normativa de Vivienda, Plan de Vivienda 2009-2012. www.madrid.org/. (Fecha de consulta: 5 de junio de 2013).

${ }_{66}$ De acuerdo al método de valoración de vivienda protegida descalificable propuesto.

(C) UNED. Revista de Derecho UNED, núm. 12, 2013 
EMPRESA MUNICIPAL DE LA VIVIENDA Y SUELO DE MADRID, S.A. ÁREA DE GOBIERNO DE URBANISMO. AYTO. DE MADRID, Reglamento de Adjudicación de Viviendas con Protección Pública afectas a los Programas Municipales de Vivienda a aplicar por la EMVS, aprobado por el Ayuntamiento de Madrid en sesión ordinaria de fecha 30 de octubre de 2012. www.emvs.es/. (Fecha de consulta: 5 de junio de 2013).

LASARTE ÁlVAREZ, Carlos, Principios de Derecho Civil, VI. Derecho de familia, Marcial Pons, Madrid, 2012, 11. ${ }^{\text {a }}$ ed.

MORALES MORENO, Ángeles Leticia, Ejecución de las sentencias dictadas en los procedimientos de familia, Tirant lo Blanch, Valencia 2013, 1. ${ }^{\mathrm{a}}$ ed.

MORETÓN SANZ, M. ${ }^{a}$ Fernanda, «Vivienda familiar y subrogación hipotecaria en tiempos de crisis: notas sobre los pactos internos entre codeudores solidarios», Revista Crítica de Derecho Inmobiliario, 720 , págs. 1.747 a 1.767.

PAZ-ARES RODRÍGUEZ, Cándido (et alia, Dir.), Comentario del Código Civil, Tomo I y II, Ministerio de Justicia, Madrid, 1993, $2 .^{\mathrm{a}}$ ed.

PÉREZ UREÑA, Antonio Alberto, "La valoración de la vivienda de protección oficial en la liquidación de gananciales, a la luz de la praxis judicial», Boletín Derecho de Familia, 1 de noviembre de 2012, www.elderecho.com/civil/valoracion-proteccion-liquidacion-gananciales-judicial_11_478930007.html. (Fecha de consulta: 8 de junio de 2013).

RUBIO TORRANO, Enrique, «Liquidación de gananciales y valor de la VPO», Aranzadi Civil, 2, 2008, págs. 2.285 a 2.287.

SALAS CARCELLER, Antonio, "Rescisión por lesión y liquidación de sociedad de gananciales», Repertorio de Jurisprudencia, 6, 2004, págs. 303 a 305.

SÁNCHEZ CALERO, Francisco Javier (Coord.), Curso de Derecho Civil, Tirant lo Blanch, Valencia, 2012, 6. ${ }^{\text {a edición. }}$

VILLAGRASA ALCAIDE, Carlos (Coord.), Derecho de Familia, Bosch, Barcelona, 2011, 1. a edición.

ZARRALUQUI SÁNCHEZ-EZNARRIAGA, Luis, «El bosque legislativo Otrosí, 1, 4. ${ }^{a}$ etapa. 


\section{VI. ÍNDICE DE RESOLUCIONES JUDICIALES CITADAS}

STC (Sala Pleno), núm. 61/1997, de 20 de marzo (RTC 1997/61).

STC (Sala Pleno), núm. 170/1989, de 19 de octubre (RTC 1989/170).

STS de 4 de julio de 2011, Sala de lo Civil (RC 385/2007).

STS de 4 de abril de 2008, Sala de lo Civil (RJ 2008/2944).

STS de 14 de noviembre de 2002, Sala de lo Civil (RJ 2002/9921).

STS de 4 de marzo de 1997, Sala de lo Civil (RJ 1997/1640).

STS de 16 de diciembre de 1995, Sala de lo Civil (RJ 1995/9144).

STS de 11 de julio de 1995, Sala de lo Civil (RJ 1995/5958).

STS de 9 de febrero de 1995, Sala de lo Civil (RJ 1995/1631).

STS de 21 de febrero de 1994, Sala de lo Civil (RJ 1994/1106).

STS de 26 de enero de 1993, Sala de lo Civil (RJ 1993/365).

STS de 14 de octubre de 1992, Sala de lo Civil (RJ 1992/7557).

STS de 3 de septiembre de 1992, Sala de lo Civil (RJ 1992/6882).

STS de 23 de marzo de 1992, Sala de lo Civil (RJ 1992/2277).

STS de 30 de marzo de 1988, Sala de lo Civil, (RJ 1988/2570).

SAP Sta. Cruz de Tenerife, Sec. $1 .^{\text {a }}$, de 8 de abril de 2011(EDJ 2011/105385). 
